\title{
Novel Thiazole Derivatives of Medicinal Potential: Synthesis and Modeling
}

\author{
Nour E. A. Abdel-Sattar, Abeer M. El-Naggar, and M. S. A. Abdel-Mottaleb \\ Department of Chemistry, Organic Labs, and Computational Chemistry Lab, Faculty of Science, Ain Shams University, Abbasiya, \\ Cairo 11566, Egypt
}

Correspondence should be addressed to Nour E. A. Abdel-Sattar; nourel-dinahmed@sci.asu.edu.eg

Received 17 March 2017; Revised 18 May 2017; Accepted 4 June 2017; Published 24 July 2017

Academic Editor: Pedro M. Mancini

Copyright (C) 2017 Nour E. A. Abdel-Sattar et al. This is an open access article distributed under the Creative Commons Attribution License, which permits unrestricted use, distribution, and reproduction in any medium, provided the original work is properly cited.

This paper reports on the synthesis of new thiazole derivatives that could be profitably exploited in medical treatment of tumors. Molecular electronic structures have been modeled within density function theory (DFT) framework. Reactivity indices obtained from the frontier orbital energies as well as electrostatic potential energy maps are discussed and correlated with the molecular structure. X-ray crystallographic data of one of the new compounds is measured and used to support and verify the theoretical results.

\section{Introduction}

The thiazole has an important component effect of the pharmacophores of a large number of medicinal significance molecules and the evaluation of their biological activity, such as antibacterial [1], antiprotozoal [2], antitubercular [3], antifungal $[4,5]$, and anthelmintic [6], with emphasis on their potential medicinal applications, is desirable. Here we are interested to study newly synthetized aminothiazoles, especially 2 -aminothiazole derivatives which represent a class of heterocyclic ring system possessing antiviral [7], antimicrobial [8], anticancer [9], and anti-inflammatory activities [10]. Previously, in vitro anticancer evaluation studies of different 2-aminothiazole analogs exhibited their potent and selective nanomolar inhibitory activity against a wide range of human cancerous cell lines such as breast, leukemia, lung, colon, CNS, melanoma, ovarian, renal, and prostate cell lines [11-14]. Substitutions at 2-position benzothiazole have emerged in its usage as a core structure in the diversified therapeutic applications [15-21]. The studies of structureactivity relationship interestingly reveals that change of the structure of substituent group at C-2 position commonly results in the change of its bioactivity. Though literature survey reports many therapeutic applications of 2 -substituted benzothiazoles, their investigation for anti-inflammatory activity is limited [16, 22-25]. Furthermore, thiazole derivatives have attracted a great deal of interest due to their wide applications in the field of pharmaceuticals. Thiazole derivatives display a wide range of biological activities such as cardiotonic, fungicidal, sedative, anesthetic, bactericidal, and anti-inflammatory [26, 27]. In addition, thiazole derivatives are reported to show a variety of biological activities. Depending on the substituents, this heterocycle possesses anthelmintic, antibiotic, and immunosuppressant activity [28]. Recent research indicates that some of 2-aminothiazoles derivatives are inhibitors of enzymes such as kynurenine-3hydroxylase 29 or possess inhibitors activity against enzyme cyclin-dependent kinase [29].

Additionally, monoazo disperse dyes with thiazole-diazo components have been intensively investigated to produce bright and strong color shades ranging from red to greenish blue on synthetic fiber. Color Index described various basic, direct, vat, and disperse dyes wherein thiazole nucleus occurs [30]. Derivative of 2-aminothiazole has a long history of use as heterocyclic diazo components for disperse dyes [31].

In the present study, quantum chemical computations will be performed within DFT using WB97XD/6-31G(d) model to investigate the molecular structure, IR, and NMR of the newly synthetized molecules [32-38]. X-ray crystallographic data of $3 \mathrm{~B}$ will be obtained and used to support 
and verify the theoretical results. The energies of HOMOLUMO frontier orbitals will be used to estimate molecular reactivation towards nucleophilic/electrophilic reagents. Electrostatic potential energy maps (ESP maps) will be graphically presented to locate binding sites of these new derivatives.

\section{Experimental Section}

2.1. Synthesis. All melting points were measured on an electric melting point apparatus and were uncorrected. The infrared spectra were recorded using potassium bromide disks on a Pye Unicam SP-3-300 infrared spectrophotometer; the established values of the gas phase frequencies are given between brackets. ${ }^{1} \mathrm{HNMR}$ spectra were run at $300 \mathrm{MHz}$, on a Varian Mercury VX-300 NMR spectrometer and Brukeravance III $400 \mathrm{MHZ}$, using TMS as an internal standard in deuterated dimethylsulphoxide. Chemical shifts $\delta$ are quoted in $\mathrm{ppm}$. The mass spectra were recorded on Shimadzu GCMS-QP-1000EX mass spectrometers at $70 \mathrm{eV}$. All the spectral measurements were carried out at the NMR Laboratory of Cairo University, Egypt, and the NMR Laboratory of Faculty of Pharmacy, Ain shams University, Egypt; the microanalytical data were measured in Central Lab of Cairo University, Egypt; the Ministry of Defense Chemical Laboratories, Egypt; and the Microanalytical Center of Ain Shams University, Egypt. All the chemical reactions were monitored by TLC. The bold values corresponded to values calculated from DFT.

2.1.1. General Procedure for the Preparation of Compounds $2 \boldsymbol{a}-\boldsymbol{g}$. A mixture of 2-aminothiazole $1(1 \mathrm{~g}, 10 \mathrm{mmol})$ and different electrophilic reagents, namely, 2-chloro-N-(4sulfamoylphenyl) acetamide, ethyl chloroacetate, phenyl cyanate, chloroacetyl chloride, 2-chloro-N-(4-chlorophenyl) acetamide, phenyl cyanate, phenyl thiocyanate, chloroacetyl chloride and 2-chloro-N-(4-chlorophenyl) acetamide $(10 \mathrm{mmol})$ in dimethylformamide $(20 \mathrm{ml})$, and anhydrous potassium carbonate, was refluxed for $5-8 \mathrm{~h}$. The reaction mixture was poured in ice water $(200 \mathrm{ml})$; the formed ppt was filtered off, dried, and crystallized from ethanol afforded compounds $2 \mathbf{a}-\mathbf{g}$. It should be noticed that quantum chemically calculated spectroscopic parameters in gaseous phase are given in \{bold font\} for comparison with the experimentally obtained parameters.

N-(4-Sulfamoylphenyl)-2-(thiazol-2-ylamino) Acetamide (2a). Yield $65 \%$; m.p. $118-120^{\circ} \mathrm{C}$; orange crystals; (EtOH); IR $(\mathrm{KBr})$ broad band at $3378,3325,3273 \mathrm{~cm}^{-1}\left(\nu_{\mathrm{NH}}\right), 3022 \mathrm{~cm}^{-1}$ $\left(v_{\text {Aromatic }}\right), 2958 \mathrm{~cm}^{-1}\left(v_{\text {Aliphatic }}\right), 1691 \mathrm{~cm}^{-1}\left(v_{\mathrm{C}=\mathrm{O}}\right) .{ }^{1} \mathrm{HNMR}$ (300 MHz, DMSO-d $\left.{ }_{6}\right) \delta$ ppm: $5.1\left(\mathrm{~s}, 2 \mathrm{H}, \mathrm{CH}_{2}\right), 7.15(\mathrm{~d}, 1 \mathrm{H}$, thiazole $\mathrm{H}, J=8.6 \mathrm{~Hz}), 7.4(\mathrm{~d}, 1 \mathrm{H}$, thiazole $\mathrm{H}, J=8.6 \mathrm{~Hz}), 7.2$ (s, $2 \mathrm{H}, \mathrm{NH}_{2}, \mathrm{D}_{2} \mathrm{O}$ exchangeable), $7.7(\mathrm{~d}, 2 \mathrm{H}, \mathrm{Ar}-\mathrm{H}), 7.8(\mathrm{~d}, 2 \mathrm{H}$, Ar- $\mathrm{H}), 10.8$ (s, $1 \mathrm{H}, \mathrm{D}_{2} \mathrm{O}$ exchangeable $\mathrm{NH}$ ), 7.1 and 12 (br s, $1 \mathrm{H}$, $\mathrm{D}_{2} \mathrm{O}$ exchangeable $\mathrm{NH}-\mathrm{OH}$ tautomerism). Anal. Calculated for $\mathrm{C}_{11} \mathrm{H}_{12} \mathrm{~N}_{4} \mathrm{O}_{3} \mathrm{~S}_{2}$ (312.36): C, 42.30; H, 3.87; N, 17.94 Found: C, 42.01; H, 4.07; N, 17.84 .
Ethyl thiazole-2-ylglycinate (2b). Yield 80\%; m.p. $142-144^{\circ} \mathrm{C}$; orange crystals; (EtOH); IR (KBr) $3346 \mathrm{~cm}^{-1}\left(\nu_{\mathrm{NH}}\right)$, $3045 \mathrm{~cm}^{-1} \quad\left(v_{\text {Olefinic }}\right), \quad 1730 \mathrm{~cm}^{-1}$ ester $\left(v_{\mathrm{C}=\mathrm{O}}\right) .{ }^{1} \mathrm{HNMR}$ (300 MHz, DMSO-d6) $\delta$ ppm: 1.4 (trip, 3H, CH3), 3.2 (quar, $2 \mathrm{H}, \mathrm{CH} 2), 5.1(\mathrm{~S}, 2 \mathrm{H}, \mathrm{CH} 2), 7.0(\mathrm{~d}, 1 \mathrm{H}$, thiazole $\mathrm{H}, J=8.4 \mathrm{~Hz})$, $7.4(\mathrm{~d}, 1 \mathrm{H}$, thiazole $\mathrm{H}, J=8.4 \mathrm{~Hz}), 10.2(\mathrm{~s}, 1 \mathrm{H}, \mathrm{NH}, \mathrm{D} 2 \mathrm{O}$ exchangeable), Anal. Calculated for $\mathrm{C}_{7} \mathrm{H}_{10} \mathrm{~N}_{2} \mathrm{O}_{2} \mathrm{~S}$ (186.23): C, 45.15; H, 5.41; N, 15.04, Found: C, 45.01; H, 5.37; N, 14.84 .

1-Phenyl-3-(thiazole-2-yl) Urea (2c). Yield 78\%; m.p. $125-127^{\circ} \mathrm{C}$; yellow crystals; (EtOH/benzene); IR (KBr) 3326, $3284 \mathrm{~cm}^{-1}\left(v_{\mathrm{NH}}\right), 3063 \mathrm{~cm}^{-1}\left(v_{\text {Aromatic }}\right), 1648 \mathrm{~cm}^{-1}\left(v_{\mathrm{C}=\mathrm{O}}\right)$. ${ }^{1}$ HNMR (300 MHz, DMSO-d6) $\delta$ ppm: 7.00 (d, 2H, $J$ $=7.2 \mathrm{HZ}) 7.4(\mathrm{~m}, 3 \mathrm{H}, \mathrm{ArH}), 7.1(\mathrm{~d}, 1 \mathrm{H}$, thiazole $\mathrm{H}, J=$ $8.0 \mathrm{~Hz}), 7.8(\mathrm{~d}, 1 \mathrm{H}$, thiazole $\mathrm{H}, J=8.0 \mathrm{~Hz}), 8.9(\mathrm{~s}, 1 \mathrm{H} \mathrm{NH}$, D2O exchangeable,), $10.6(\mathrm{~s}, 1 \mathrm{H}, \mathrm{NH}, \mathrm{D} 2 \mathrm{O}$ exchangeable), ${ }^{13} \mathrm{CNMR} \quad(300 \mathrm{MHz}$, DMSO-d6) $\delta$ ppm: 90.3, 100.2, 105.7, 120.8, 138.5, 140.9, 159.3, 165.4, Anal. Calculated for $\mathrm{C}_{10} \mathrm{H}_{9} \mathrm{~N}_{3} \mathrm{OS}$ (219.26): C, 54.78; H, 4.14; N, 19.16, Found: C, 54.52; H, 4.17; N, 18.94 .

1-Phenyl-3-(thiazole-2-yl) Thiourea (2d). Yield 76\%; m.p. $178-180^{\circ} \mathrm{C}$; brownish red crystals; (butanol); IR (KBr) 3169, $3081 \mathrm{~cm}^{-1}\left(\nu_{\mathrm{NH}}\right), 3009 \mathrm{~cm}^{-1}\left(\nu_{\text {aromatic }}\right) .{ }^{1} \mathrm{HNMR}(300 \mathrm{MHz}$, DMSO-d6) $\delta$ ppm: 7.00 (d, 2H, J = 7.2 HZ), 7.4 (m, 3H, ArH), $7.4(\mathrm{~d}, 1 \mathrm{H}$, thiazole $\mathrm{H}, J=7.8 \mathrm{~Hz}), 7.6(\mathrm{~d}, 1 \mathrm{H}$, thiazole $\mathrm{H}, J$ $=7.8 \mathrm{~Hz}), 10.4\left(\mathrm{~s}, 1 \mathrm{H}, \mathrm{NH}, \mathrm{D}_{2} \mathrm{O}\right.$ exchangeable $), 12.4(\mathrm{~s}, 1 \mathrm{H}$, $\mathrm{NH}, \mathrm{D}_{2} \mathrm{O}$ exchangeable), ${ }^{13} \mathrm{CNMR}(300 \mathrm{MHz}$, DMSO-d6) $\delta$ ppm: 125.3, 126.4, 128.7, 129.4, 111.2, 137.4, 162.4, 176.6, Anal. Calculated for $\mathrm{C}_{10} \mathrm{H}_{9} \mathrm{~N}_{3} \mathrm{~S}_{2}$ (235.32): C, $51.04 ; \mathrm{H}, 3.86 ; \mathrm{N}, 17.86$, Found: C, 51.01; H, 4.07; N, 17.74 .

2-Chloro-N-(thiazole-2-yl) Acetamide (2e). Yield 60\%; m.p. $220-222^{\circ} \mathrm{C}$; brownish red crystals; m.p. $162-164^{\circ} \mathrm{C}$ (butanol); IR $(\mathrm{KBr}) 3187 \mathrm{~cm}^{-1}\{3643\} \quad\left(\nu_{\mathrm{NH}}\right), 3041 \mathrm{~cm}^{-1}\left(\nu_{\text {olefinic } \mathrm{H}}\right)$, $1703 \mathrm{~cm}^{-1}\{1825\}\left(v_{\mathrm{C}=\mathrm{O}}\right) .{ }^{1} \mathrm{HNMR}(300 \mathrm{MHz}$, DMSO-d6): $\delta$ ppm: $4.5(\mathrm{~s}, 2 \mathrm{H}, \mathrm{CH} 2), 7.2(\mathrm{~d}, 1 \mathrm{H}$, thiazole $\mathrm{H}, J=8.2 \mathrm{~Hz}), 7.6$ (d, $1 \mathrm{H}$, thiazole $\mathrm{H}, J=8.2 \mathrm{~Hz}), 12.4\left(\mathrm{~s}, 1 \mathrm{H}, \mathrm{NH}, \mathrm{D}_{2} \mathrm{O}\right.$ exchangeable), ${ }^{13} \mathrm{CNMR}$ (300 MHz, DMSO-d6) $\delta$ ppm: $39.7,114.5$, 137.7, 157.8, 157.6, 164.4, Anal. Calculated for $\mathrm{C}_{5} \mathrm{H}_{5} \mathrm{ClN}_{2} \mathrm{OS}$ (176.62): C, 34.00; H, 2.85; N, 15.86, Found: C, 34.12; H, 3.07; $\mathrm{N}, 15.74$.

$\mathrm{N}$-(4-Chlorophenyl)-2-(thiazole-2-ylamino) Acetamide (2f). Yield 68\%; m.p. $198-200^{\circ} \mathrm{C}$; red crystals; (butanol); IR $(\mathrm{KBr}) 3292,3184 \mathrm{~cm}^{-1}\left(\nu_{\mathrm{NH}}\right), 3047 \mathrm{~cm}^{-1}\left(\nu_{\text {Aromatic }}\right), 1694 \mathrm{~cm}^{-1}$ $\left(v_{\mathrm{C}=\mathrm{O}}\right) .{ }^{1} \mathrm{HNMR}$ (300 MHz, DMSO-d6) $\delta$ ppm: 2.4, 2.6 (s, $2 \mathrm{H}, 2 \mathrm{NH}, \mathrm{D} 2 \mathrm{O}$ exchangeable), $7.1\left(\mathrm{~s}, 2 \mathrm{H}, \mathrm{CH}_{2}\right), 7.2(\mathrm{~d}, 2 \mathrm{H}$, $J=7.6 \mathrm{~Hz}), 7.6(\mathrm{~m}, 3 \mathrm{H}, \mathrm{ArH}), 8.0(\mathrm{~d}, 1 \mathrm{H}$, thiazole $\mathrm{H}, J=$ $8.2 \mathrm{~Hz}), 8.2(\mathrm{~d}, 1 \mathrm{H}$, thiazole $\mathrm{H}, J=8.2 \mathrm{~Hz})$ Anal. Calculated for $\mathrm{C}_{11} \mathrm{H}_{10} \mathrm{ClN}_{3} \mathrm{OS}$ (267.73): C, 34.35; H, 3.76; N, 15.70, Found: C, 34.12; H, 3.67; N, 15.74 .

2.1.2. General Procedure for the Preparation of Compounds $3 \boldsymbol{a}-\boldsymbol{e}$. A mixture of $\mathbf{2 e}(1.76 \mathrm{~g}, 10 \mathrm{mmol})$ and different nucleophilic reagents, namely, p-toluidine, thiourea, anthranilic, aminothiophenol, and quinoxaline-2,3-diol $(10 \mathrm{mmol})$ in dimethylformamide $(20 \mathrm{ml})$ and anhydrous potassium carbonate was refluxed for $4-5 \mathrm{~h}$. The reaction mixture was 
poured onto ice water $(200 \mathrm{ml})$. The formed precipitate was filtered off and recrystallized from the suitable solvent to afford compounds $3 a-e$.

3-(Thiazole-2-ylamino) Benzo[e][1,4]oxazepin-5(1H)-one $(3 a)$. Recrystallized from ethanol to produce brownish red crystals, Yield 84\%; m.p. $252-254^{\circ} \mathrm{C}$; (butanol); IR (KBr) $3672,3377 \mathrm{~cm}^{-1}$ \{3677 asym, 3680 sym $\}\left(\nu_{\mathrm{NH}}\right), 3198 \mathrm{~cm}^{-1}$ $\{3267$ asym str $\} \quad\left(\nu_{\mathrm{H} \text { of thiazole }}\right), \quad 3020 \mathrm{~cm}^{-1} \quad\left(\nu_{\text {Aromatic }}\right)$, $2967.42 \mathrm{~cm}^{-1}\{3095 \mathrm{sym} \mathrm{str}\} \quad\left(v_{\mathrm{CH} 2}\right) \quad 1698 \mathrm{~cm}^{-1} \quad\left(v_{\mathrm{C}=\mathrm{O}}\right)$. ${ }^{1} \mathrm{HNMR}(300 \mathrm{MHz}$, DMSO-d6) $\delta$ ppm: $7.2(\mathrm{~d}, 1 \mathrm{H}$, thiazole $\mathrm{H}, J=8.2 \mathrm{~Hz}), 7.4(\mathrm{~d}, 1 \mathrm{H}$, thiazole $\mathrm{H}, J=8.2 \mathrm{~Hz}), 7.6(\mathrm{~d}, 2 \mathrm{H}$, $\mathrm{ArH}, J=8.1 \mathrm{~Hz}), 7.8(\mathrm{~m}, 2 \mathrm{H}, \operatorname{ArH}), 8.2\left(\mathrm{~s}, 1 \mathrm{H}, \mathrm{NH}, \mathrm{D}_{2} \mathrm{O}\right.$ exchangeable), 8.8 (s, $1 \mathrm{H}$, 1-ethelyene), $11.4\left(\mathrm{~s}, 1 \mathrm{H}, \mathrm{NH}, \mathrm{D}_{2} \mathrm{O}\right.$ exchangeable), Anal. Calculated for $\mathrm{C}_{12} \mathrm{H}_{9} \mathrm{~N}_{3} \mathrm{O}_{2} \mathrm{~S}$ (259.28): C, 55.59; H, 3.50; N, 16.21, Found: C, 55.45; H, 3.67; N, 16.14 .

$N$-(Thiazole-2-yl)-2-(p-tolylamino) Acetamide (3b). Oily product, solidified with diethyl ether, Yield 44\%; m.p. $235-237^{\circ} \mathrm{C}$; brownish red crystals; (butanol); IR ( $\left.\mathrm{KBr}\right) 3287$, $3150 \mathrm{~cm}^{-1}\left(\nu_{\mathrm{NH}}\right), 3045 \mathrm{~cm}^{-1}\left(v_{\text {Aromatic }}\right), 1701 \mathrm{~cm}^{-1}\left(v_{\mathrm{C}=\mathrm{O}}\right)$. ${ }^{1} \mathrm{HNMR}(300 \mathrm{MHz}$, DMSO-d6) $\delta \mathrm{ppm}: 2.11$ (s, 3H, CH3), 3.5 (s, 2H CH2), 6.25 (6.32) (d, 2H, Ar benz, $J=6.8 \mathrm{~Hz}$ ), 6.41 (6.52) $(\mathrm{d}, 1 \mathrm{H}$, thiazole $\mathrm{H}, J=8.2 \mathrm{~Hz}), 7.0(7.1)(\mathrm{d}, 2 \mathrm{H}, \mathrm{ArH}$, $J=8.1 \mathrm{~Hz}), 7.3(7.4)(\mathrm{d}, 1 \mathrm{H}$, thiazole $\mathrm{H}, J=8.2 \mathrm{~Hz}), 8.01(7.8)$ $(\mathrm{d}, 2 \mathrm{H}, \mathrm{ArH}, J=6.8 \mathrm{~Hz}), 11.4\left(\mathrm{~s}, 1 \mathrm{H}, \mathrm{NH}, \mathrm{D}_{2} \mathrm{O}\right.$ exchangeable), Anal. Calculated for $\mathrm{C}_{12} \mathrm{H}_{13} \mathrm{~N}_{3}$ OS (247.32): C, 58.28; H, 5.30; N, 16.99, Found: C, 58.45; H, 5.67; N, 16.80 .

4-(Thiazole-2-ylamino)-1,5-dihydro-2H-imidazole-2-thione (3c). Dried and crystallized from ethanol the product has brownish red crystals; m.p. 206-208 ${ }^{\circ} \mathrm{C}$; Yield 54\%; (butanol); IR $(\mathrm{KBr}) 3374,3275 \mathrm{~cm}^{-1}\left(\nu_{\mathrm{NH}}\right), 3045 \mathrm{~cm}^{-1} \quad\left(v_{\text {Aromatic }}\right)$, $2600 \mathrm{~cm}^{-1}\left(v_{\mathrm{SH}}\right), 1260 \mathrm{~cm}^{-1} \quad\left(v_{\mathrm{C}=\mathrm{S}}\right),{ }^{1} \mathrm{HNMR} \quad(300 \mathrm{MHz}$, DMSO-d6) $\delta$ ppm: $4.22(\mathrm{~s}, 2 \mathrm{H}$, imidazole $\mathrm{H}), 6.9(\mathrm{~d}, 1 \mathrm{H}$, thiazole $\mathrm{H}, J=7.4 \mathrm{~Hz}), 77.2(\mathrm{~d}, 1 \mathrm{H}$, thiazole $\mathrm{H}, J=7.4 \mathrm{~Hz}), 9.5$ (s, $\mathrm{H}, \mathrm{NH}, \mathrm{D}_{2} \mathrm{O}$ exchangeable), $13.2\left(\mathrm{~s}, \mathrm{H}\right.$, imidazole $\mathrm{NH}, \mathrm{D}_{2} \mathrm{O}$ exchangeable), Anal. Calculated for $\mathrm{C}_{6} \mathrm{H}_{6} \mathrm{~N}_{4} \mathrm{~S}_{2}$ (198.00): C, 36.35; H, 3.05; N, 28.26 Found: C, 36.45; H, 3.25; N, 28.32.

$N$-(Thiazole-2-yl)-4H-benzo[b][1,4] thiazine-2-amine (3d). Dried and crystallized from butanol, Yield 62\%; brownish red crystals; m.p. $262-266^{\circ} \mathrm{C}$; (butanol); IR ( $\left.\mathrm{KBr}\right) 3445.47$, $3310.31 \mathrm{~cm}^{-1}\{3713$ str, hetero ring, 3680 str, link $\mathrm{NH}\}\left(\nu_{\mathrm{NH}}\right)$, $3198.45 \mathrm{~cm}^{-1}\{3247\} \quad\left(v_{\mathrm{CH} \text { ring }}\right), \quad 3063 \mathrm{~cm}^{-1} \quad\left(v_{\text {Aromatic }}\right)$, $1663.89 \mathrm{~cm}^{-1}\{1639\} \quad\left(v_{\mathrm{C}=\mathrm{N} \text { triazol }}\right),{ }^{1} \mathrm{HNMR} \quad(300 \mathrm{MHz}$, DMSO-d6) $\delta$ ppm: 5.1 (s, H, Thiazine H), 7.0 (d, 2H, ArH, $J$ $=7.9 \mathrm{~Hz}), 7.4(\mathrm{~m}, 2 \mathrm{H}, \mathrm{ArH}), 7.5(\mathrm{~d}, 1 \mathrm{H}$, thiazole $\mathrm{H}, J=8.2 \mathrm{~Hz})$, $7.6(\mathrm{~d}, 1 \mathrm{H}$, thiazole $\mathrm{H}, J=8.2 \mathrm{~Hz}), 10.8,12.2(\mathrm{~s}, 2 \mathrm{H}, 2 \mathrm{NH}$, D2O exchangeable), ${ }^{13} \mathrm{CNMR}$ (300 MHz, DMSO-d6) $\delta$ ppm: 114.6, 122.2, 123.7, 124.6, 126.8, 141.0, 153.6, 155.7, 165.4, Anal. Calculated for $\mathrm{C}_{11} \mathrm{H}_{9} \mathrm{~N}_{3} \mathrm{~S}_{2}(247.33)$ : $\mathrm{C}, 53.42 ; \mathrm{H}, 3.67 ; \mathrm{N}, 16.99$, Found: C, 36.45; H, 3.25; N, 28.32.

2-((3-Hydroxyquinoxalin-2-yl)oxy)-N-(thiazole-2-yl) Acetamide (3e). Crystallized from ethanol, Yield 58\%; m.p. $298-300^{\circ} \mathrm{C}$; brownish red crystals; (butanol); IR ( $\mathrm{KBr}$ ) broad band at $3450 \mathrm{~cm}^{-1}$ \{3787 of hetero ring $\}\left(\nu_{\mathrm{OH}}\right)$, $3342 \mathrm{~cm}^{-1}\{3643$ of hetero ring $\} \quad\left(\nu_{\mathrm{NH}}\right), \quad 3190 \mathrm{~cm}^{-1}\{3256\}$
$\left(v_{\mathrm{CH} \text { of hetero ring }}\right), \quad 3120 \mathrm{~cm}^{-1}\{3107\} \quad\left(v_{\mathrm{CH} 2}\right), \quad 3048 \mathrm{~cm}^{-1}$ $\left(v_{\text {Aromatic }}\right), \quad 1725 \mathrm{~cm}^{-1}\{1834\} \quad\left(v_{\mathrm{C}=\mathrm{O}}\right), \quad 1658 \mathrm{~cm}^{-1} \quad\left(v_{\mathrm{C}=\mathrm{N}}\right)$. ${ }^{1}$ HNMR (300 MHz, DMSO-d6) $\delta$ ppm: $5.4(\mathrm{~s}, 2 \mathrm{H}, \mathrm{CH} 2), 7.4$ $\left(\mathrm{s}, 1 \mathrm{H}, \mathrm{NH}, \mathrm{D}_{2} \mathrm{O}\right.$ exchangeable), $7.5(\mathrm{~d}, 2 \mathrm{H}, \mathrm{ArH}, J=8.2 \mathrm{~Hz}$ ), $7.7(\mathrm{~m}, 2 \mathrm{H}, \mathrm{ArH}), 8.0(\mathrm{~d}, 1 \mathrm{H}$, thiazole $\mathrm{H}, J=8.56 \mathrm{~Hz}), 8.2$ $(\mathrm{d}, 1 \mathrm{H}$, thiazole $\mathrm{H}, J=8.56 \mathrm{~Hz}), 13.2\left(\mathrm{~s}, 1 \mathrm{H}, \mathrm{OH}, \mathrm{D}_{2} \mathrm{O}\right.$ exchangeable), Anal. Calculated for $\mathrm{C}_{13} \mathrm{H}_{10} \mathrm{~N}_{4} \mathrm{O}_{3} \mathrm{~S}$ (302.31): C, 51.65; H, 3.33; N, 18.53, Found: C, 51.56; H, 3.21; N, 18.56.

2.2. X-Ray Crystallography. X-ray structure analysis offers perfect addition to our synthetic work. X-ray structures of the compound $3 \mathrm{~b}$ were performed in the Central Service and X-Ray Laboratories, National Research Centre, Cairo, Egypt. Crystal and molecular structures were prepared by Maxus Computer Program for the Solution and Refinement of Crystal Structures. All diagrams and calculations were performed using maXus (Bruker Nonius, Delft; MacScience, Japan). There was no extinction correction. Atomic scattering factors were from Waasmaier and Kirfel, 1995. Data collection parameters are as follows: KappaCCD; cell refinement: HKL Scalepack; data reduction: Denzo Program(s) used to solve structure; SIR92 and Scalepak Program(s) used to refine structure; maXus: ORTEP Software which was used for molecular graphics. Crystal data, fractional atomic coordinates, and equivalent isotropic thermal parameters, anisotropic displacement parameters and geometric parameters of compounds $3 \mathrm{~b}$ are given in Table 2 . The additional data for the molecule $3 \mathrm{~b}$ are alternatively available from the Cambridge Crystallographic Data Centre as CCDC1402910.

2.3. Computations. Computations were carried out using Gaussian 16 revision A.03 package [32] and/or Spartan'16 parallel QC program [Wavefunction, Inc., USA]. Optimized structures and spectroscopic data derived from quantum chemical calculations have been used within the WB97DX/631G(d) model. A Broadberry (UK) 40-core workstation and/or MAC Pro 12-core computers were used.

\section{Result and Discussion}

3.1. Synthesis and Spectroscopic Properties. In our study, 2aminothiazole 1 was used as a key starting material. Reaction of 1 with chloro-N-(4-sulfamoylphenyl) acetamide afforded the amide derivative $2 \mathrm{a}$ (Scheme 1). The structure of $2 \mathrm{a}$ is substantiated from its spectral data. The IR spectrum shows appearance of absorption band of $\mathrm{C}=\mathrm{O}$ group for the amide at $1691 \mathrm{~cm}^{-1}$, as well as the presence of OH-NH tautomerization at $\delta 7.1 \mathrm{ppm}$ and $12 \mathrm{ppm}$. On the other hand, when 1 was refluxed in dimethylformamide with ethyl chloroacetate, the ester $2 \mathrm{~b}$ was abstained and its structure was confirmed with different spectral data: the presence of the ester $\mathrm{C}=\mathrm{O}$ at $1730 \mathrm{~cm}^{-1}$ in IR, for example, and the presence of $\mathrm{CH}_{2} \mathrm{CH}_{3}$ in $\mathrm{H}-\mathrm{NMR}$ as quartet and triplet at $\delta 3.2,1.4 \mathrm{ppm}$, respectively.

In addition, urea and thiourea derivatives $2 \mathrm{c}, 2 \mathrm{~d}$ were obtained from the reaction of the aminothiazole with phenyl isocyanate and phenyl isothiocyanate. The IR spectrum revealed the absence of doublet bands of $\mathrm{NH}_{2}$ in both compounds, the appearance of band that is attributed to 


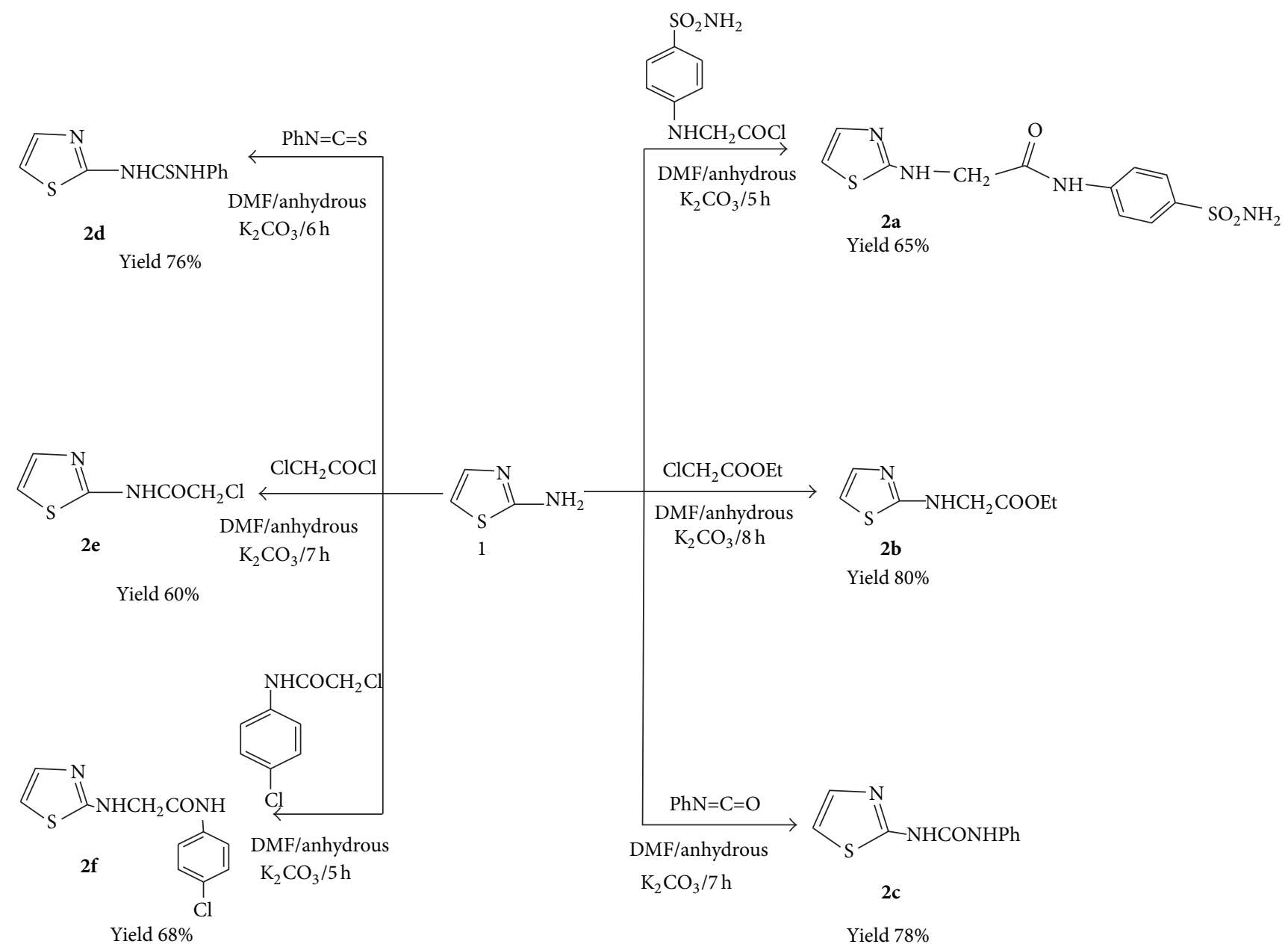

SCHEME 1

$\mathrm{C}=\mathrm{O}$ for $2 \mathrm{c}$ at $1648 \mathrm{~cm}^{-1}$, and the appearance of four peaks that is attributed to phenyl ring in $\mathrm{C}^{13}$-NMR. The most important compound in this work is compound $2 \mathrm{e}$ that resulted from interaction of 1 with chloroacetyl chloride; the structure was proved by appearance of $\mathrm{C}=\mathrm{O}$ at $1703 \mathrm{~cm}^{-1}$ as well as absence of $\mathrm{NH}_{2}$ doublets. The amide derivative $2 \mathrm{f}$ is obtained from reaction of thiazole derivative with 2-chloro$\mathrm{N}$-(4-chlorophenyl) acetamide; the IR spectrum shows the presence of $\mathrm{C}=\mathrm{O}$ band and the presence of double doublets of para-substituted-benzene ring of chlorophenyl in H-NMR.

The compound $2 \mathrm{e}$ was the key start for many other reactions; refluxing $2 \mathrm{e}$ with anthranilic acid afforded the oxazipin-one $3 \mathrm{a}$ (Scheme 2). The cyclic structure was proved from IR spectrum which showed the absence of broad $\mathrm{OH}$ band that is attributed to open structure and the appearance of $\mathrm{C}=\mathrm{O}$ band at $1698 \mathrm{~cm}^{-1}$.

On the other hand, the amide derivatives $3 \mathrm{~b}$ were obtained from reaction of 2e with p-toluidine for five hours; the open structure was confirmed with many tools as IR which show two NH bands at $3287,3150 \mathrm{~cm}^{-1}$, as well as the XRay crystallography; furthermore, refluxing of chloroderivative $2 \mathrm{e}$ with thiourea afforded cyclic structure $3 \mathrm{c}$, which had been proved with absence of $\mathrm{C}=\mathrm{O}$ band in IR and appearance of 3374 and $3275 \mathrm{~cm}^{-1}$ for $2 \mathrm{NH}$. Furthermore, the appearance of weak band as $2600 \mathrm{~cm}^{-1}$ is attributed to thionethiol SH tautomerization. The thiazine $3 \mathrm{~d}$ is another cyclic compound resulting from refluxing $2 \mathrm{e}$ with 2 -aminophenol; the structure was proved by disappearance of $\mathrm{C}=\mathrm{O}$, as well as the appearance of peak in $\mathrm{H}-\mathrm{NMR}$ for thiazine $\mathrm{H}$ at $\delta 5.1 \mathrm{ppm}$ and appearance for extra peak at $\delta 114 \mathrm{ppm}$ for thiazine ring in $\mathrm{C}^{13}$-NMR.

At last, refluxing 2e with quinoxaline-2,3-diol in DMF/ anhydrous carbonate produced the ether $3 \mathrm{e}$, whose structure was evaluated from IR by peaks at $1725 \mathrm{~cm}^{-1}$ for $\mathrm{C}=\mathrm{O}$, appearance of broad band at $3350 \mathrm{~cm}^{-1}$ that is attributed to $\mathrm{OH}$, and, in addition, aromatic peaks in H-NMR at $\delta 7.5 \mathrm{ppm}$ and $7.7 \mathrm{ppm}$.

3.2. X-Ray Crystallography and Optimized Molecular Structure. X-ray results are depicted in Table 1. X-ray structure analysis offers perfect addition to our synthetic work. X-ray structures of the compound $3 \mathrm{~b}$ (Figure 1) showed that the molecule is planar. Table 2 shows the agreement between the optimized parameters and the experimentally obtained geometry of 3B molecule. 


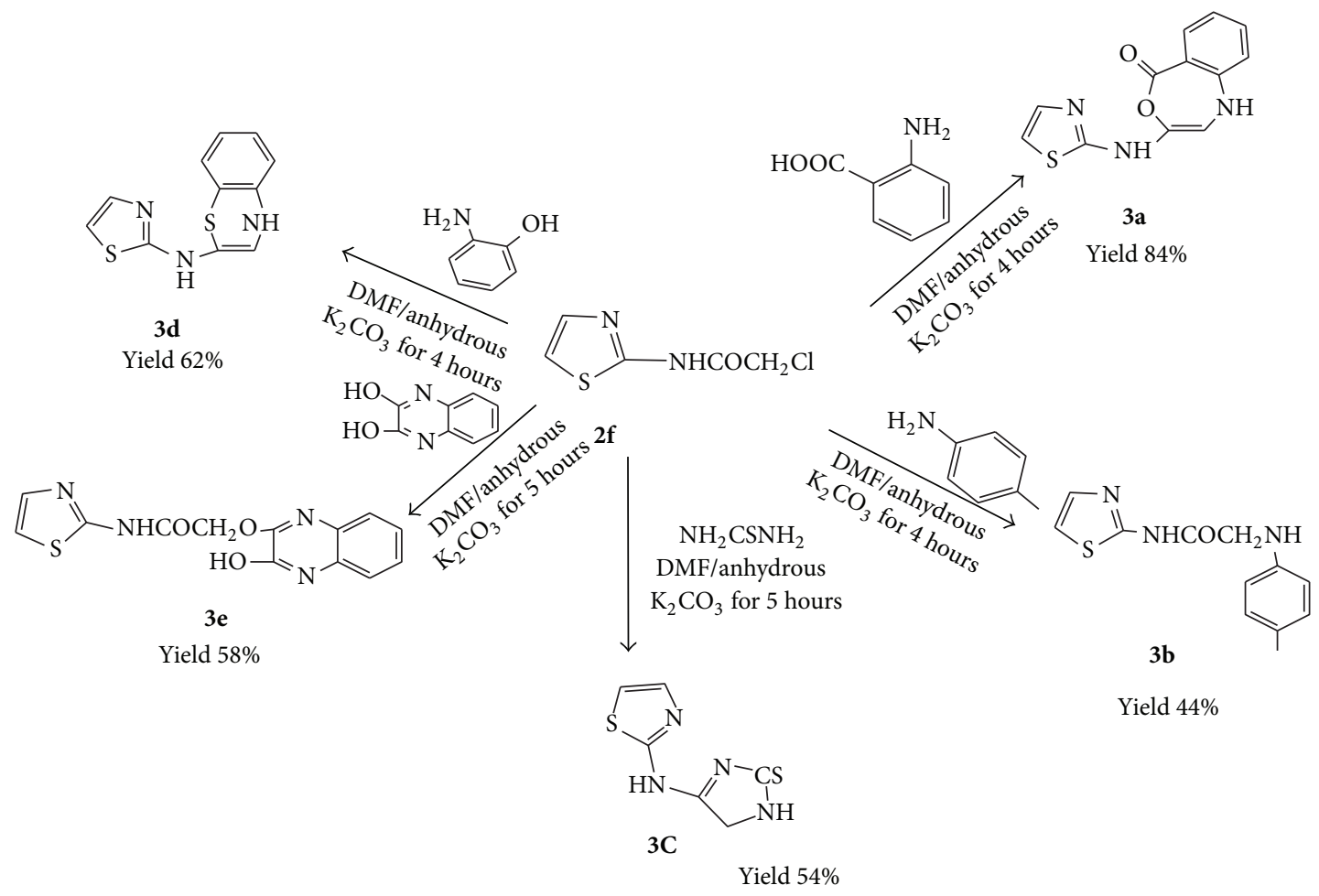

SCHEME 2

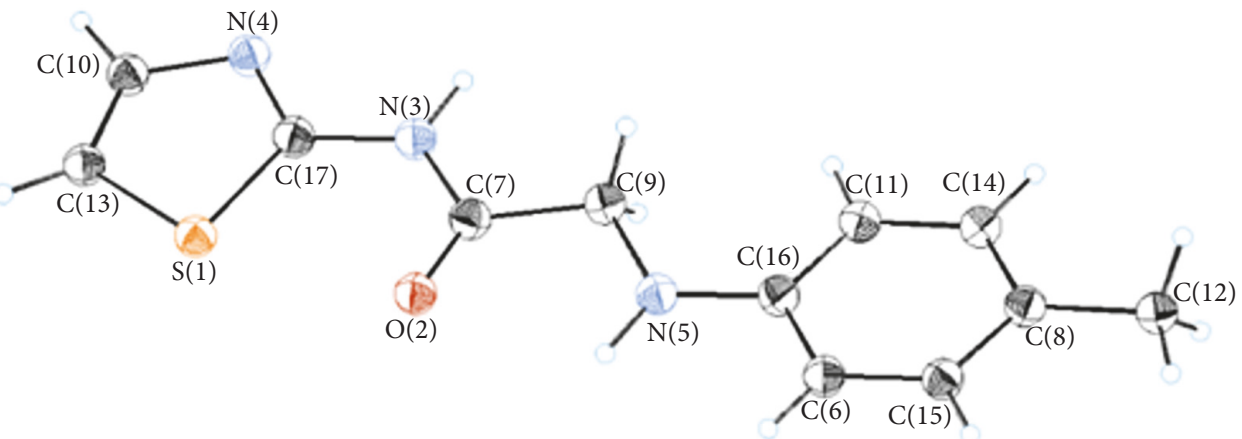

FIGURE 1: X-ray crystallographic drawing of molecule $\mathbf{3 b}$.

The structure produced (Figure 1 and Table 2) is in excellent match with the optimized structure obtained by quantum chemical calculations within the density functional theory (DFT) $[33,34]$ using WB97XD/6-31G(d) model.

3.3. Molecular Reactivities. Chemical reactivity theory quantifies the reactive propensity of isolated species through the introduction of a set of reactivity indices or descriptors. Its roots go deep into the history of chemistry, as far back as the introduction of such fundamental concepts as acid, base, Lewis acid, and Lewis base. It pervades almost all of chemistry.

The most relevant indices defined within the conceptual DFT [33] for the study of the organic reactivity are discussed elsewhere [35-39]. Molecular reactivity indices [35-39] such as chemical potential $(\boldsymbol{\mu})$, hardness $(\boldsymbol{\eta})$, and electrophilicity $(\boldsymbol{\omega})$ were computed from the energies of frontier orbitals and defined as follows:

(1) Chemical potential is given by

$$
\boldsymbol{\mu} \approx-\frac{1}{2}(I+A) \approx \frac{1}{2}\left(\epsilon_{L}-\epsilon_{H}\right)
$$

or simply $\boldsymbol{\mu}=\mathbf{0 . 5}(\mathrm{LUMO}+\mathrm{HOMO})$.

(2) Hardness is given by

$$
\boldsymbol{\eta} \approx \frac{1}{2}(I-A) \approx \frac{1}{2}\left(\epsilon_{L}-\epsilon_{H}\right)
$$

or simply $\boldsymbol{\eta}=\mathbf{0 . 5}$ (LUMO - HOMO). The chemical hardness $\boldsymbol{\eta}$ can be thought as a resistance of 

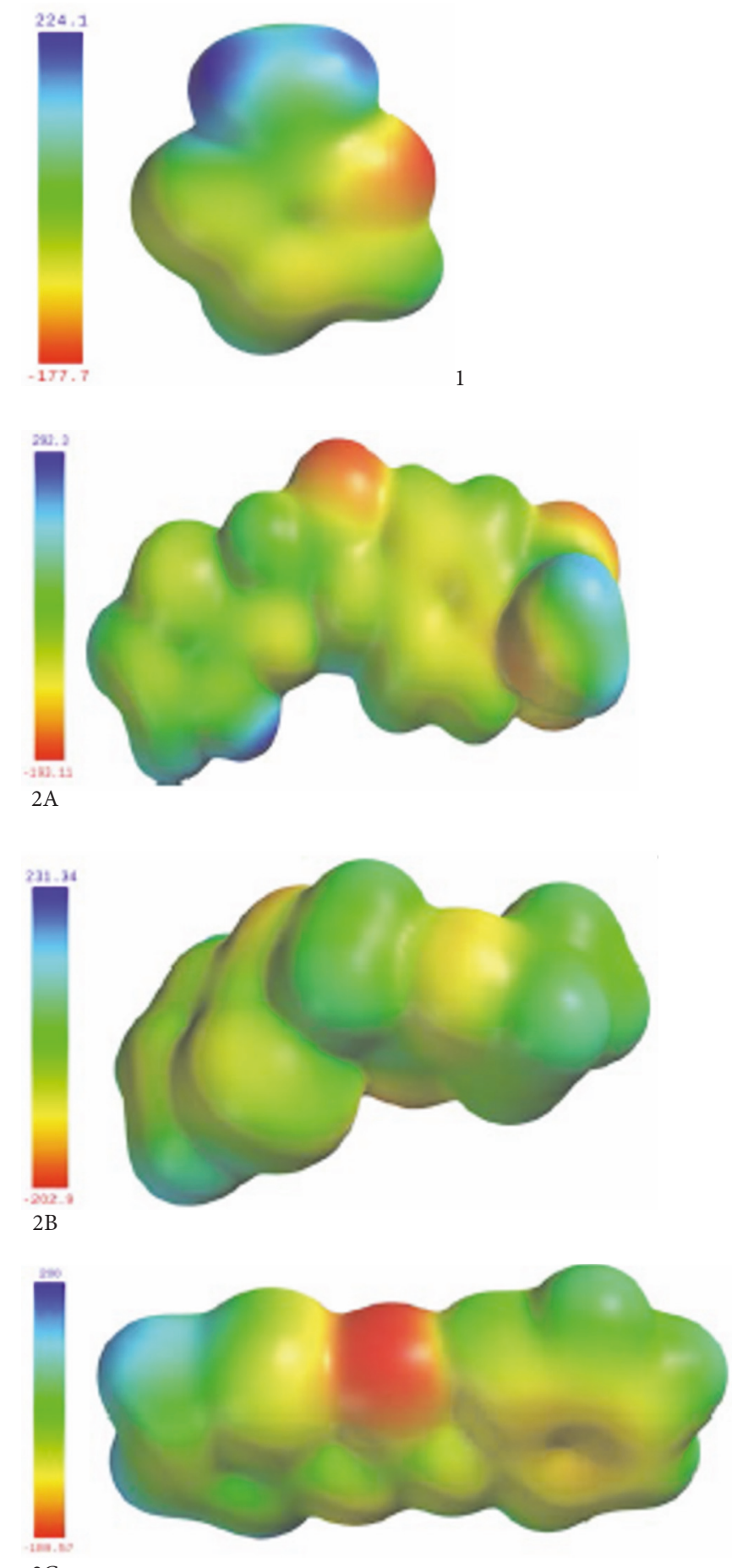

2C

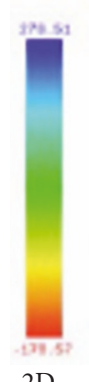

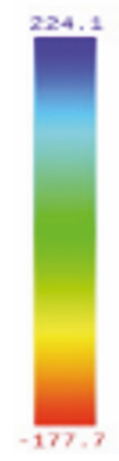
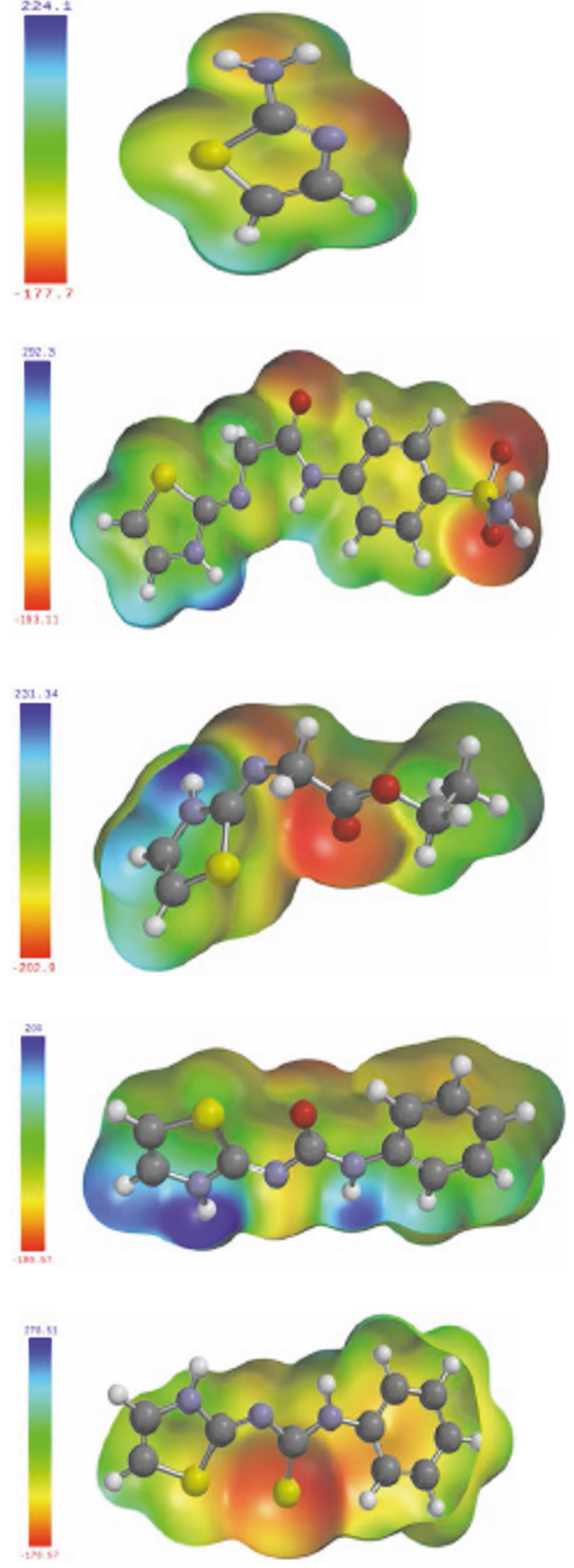

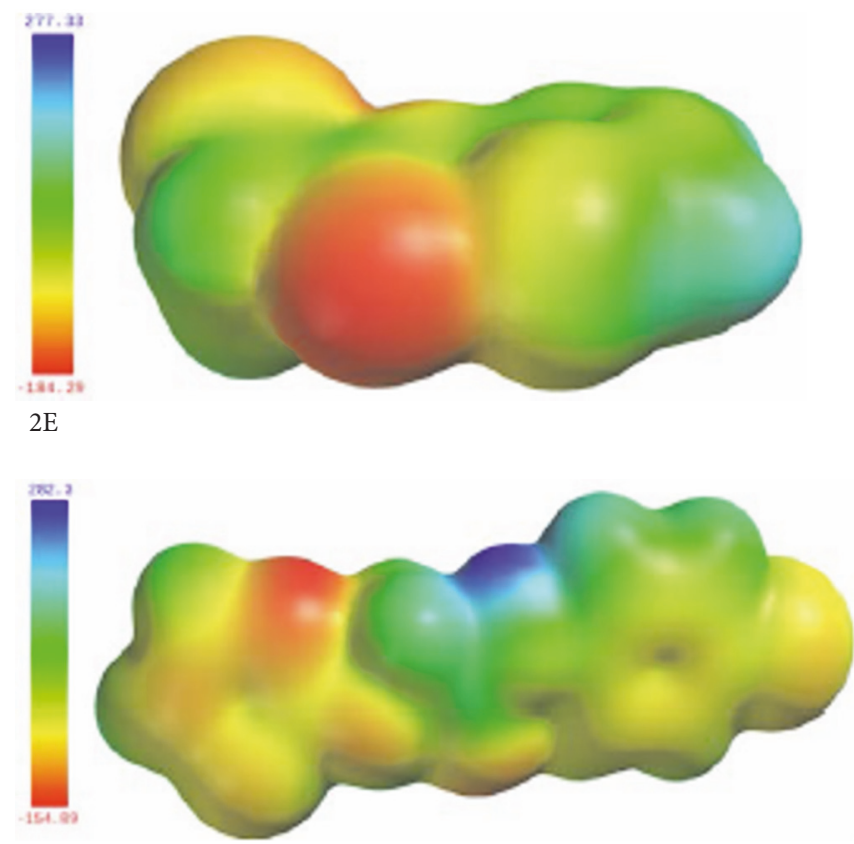

2F
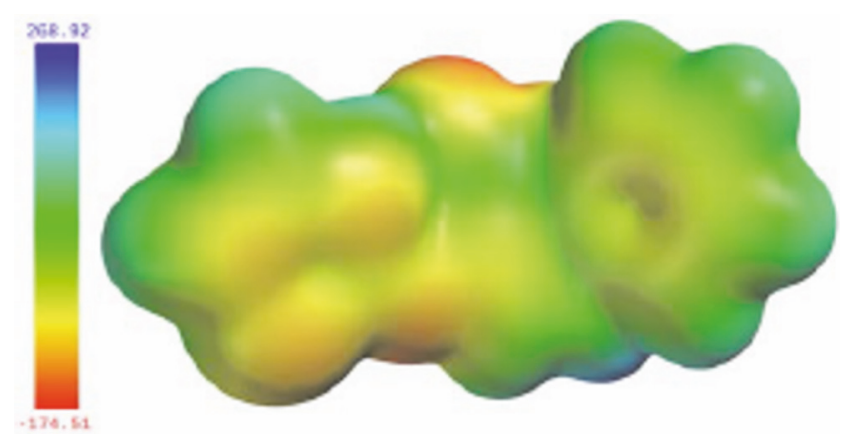

$3 \mathrm{~A}$
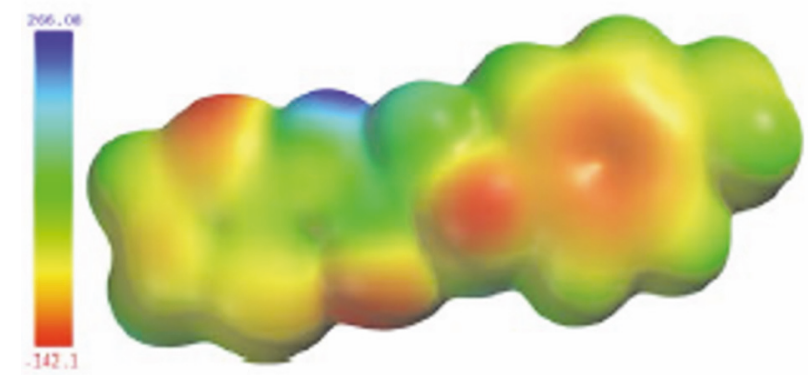

3B
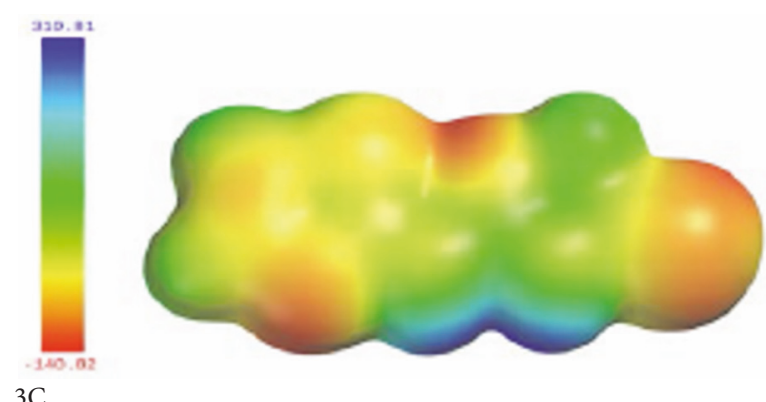

$3 \mathrm{C}$
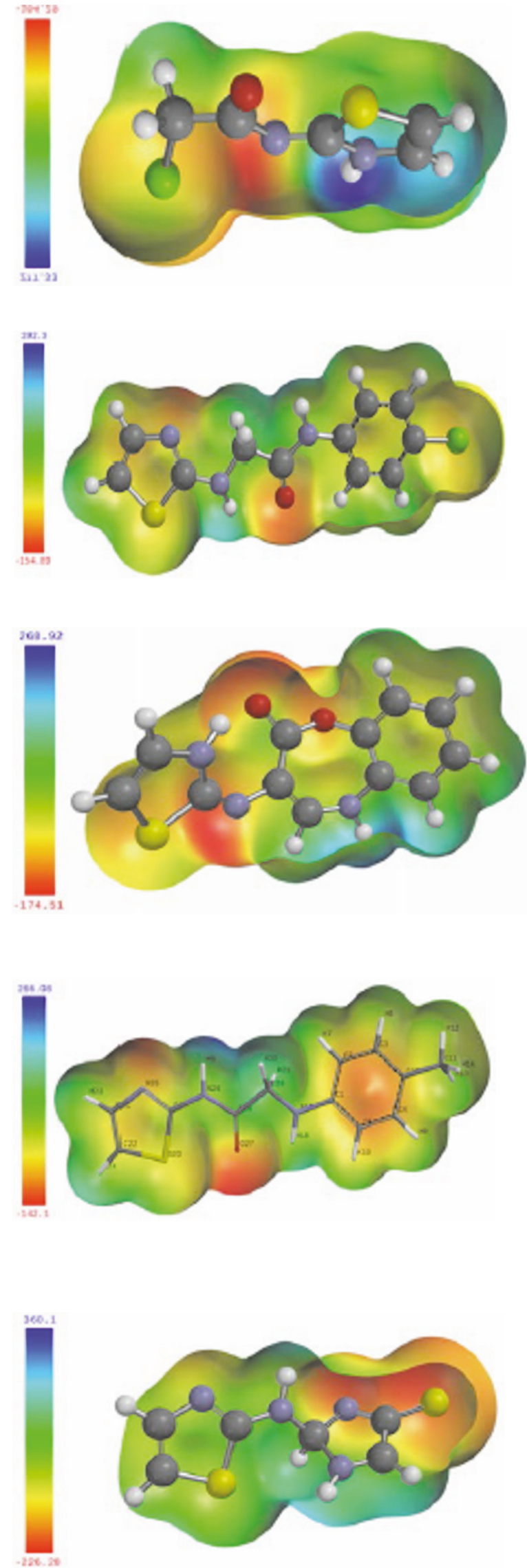

FIgure 2: Continued. 

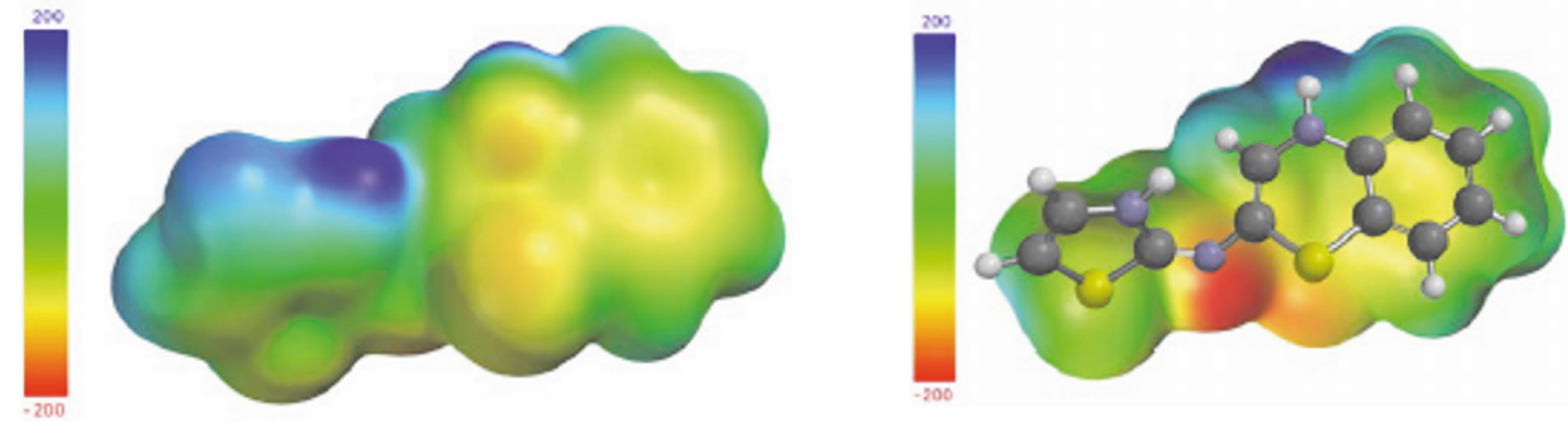

$3 \mathrm{D}$
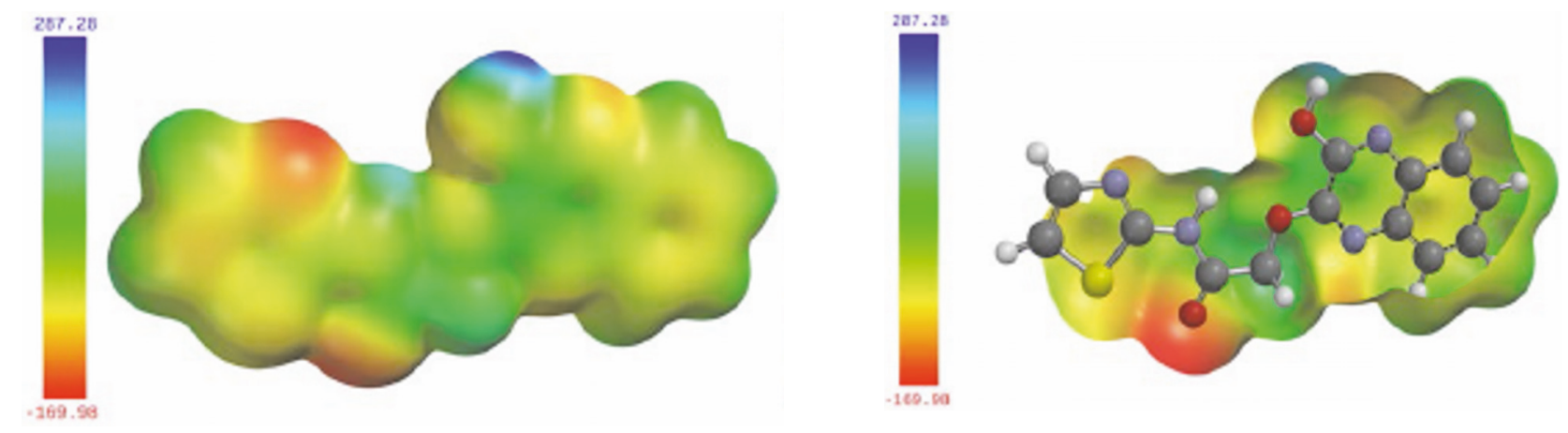

$3 \mathrm{E}$

FIGURE 2: ESP maps (solid surface at left side and clipped surfaces at the right side showing atoms). The results should improve our knowledge about the binding sites, which are of importance in medical applications. Color code bars reflect electrostatic potential energy values in $\mathrm{kJ} / \mathrm{mol}$. The redder the area is, the higher the electron density is susceptible to nucleophilic attack and the bluer the area is, the lower the electron density is that could easily binds with an electrophile.

TABLE 1: Crystal experimental data for compound $\mathbf{3 b}$.

\begin{tabular}{|c|c|}
\hline Parameter & Results \\
\hline Empirical formula & $\mathrm{C}_{12} \mathrm{H}_{13} \mathrm{~N}_{3} \mathrm{OS}$ \\
\hline Formula weight $\left(\mathrm{g} \mathrm{mol}^{-1}\right)$ & $M_{r}=247.08$ \\
\hline Temperature & $T=298 \mathrm{~K}$ \\
\hline Crystal system & Monoclinic \\
\hline Space group & $\mathrm{P} 2_{1} / \mathrm{c}$ \\
\hline$a(\AA)$ & $15.1986(6)$ \\
\hline$b \AA$ & $5.2675(2)$ \\
\hline$c \AA$ & $20.1741(10)$ \\
\hline$\alpha(\operatorname{deg})$ & $90.00^{\circ}$ \\
\hline$\beta(\mathrm{deg})$ & $110.478(2)^{\circ}$ \\
\hline$\gamma(\operatorname{deg})$ & $90.00^{\circ}$ \\
\hline$V \AA^{3}$ & $1513.04(11)$ \\
\hline$Z$ & 4 \\
\hline$D_{x}:$ & $1.288 \mathrm{Mg} \mathrm{m}^{-3}$ \\
\hline Radiation & Mo $K \alpha(\lambda=0.71073)$ \\
\hline$\mu\left(\mathrm{mm}^{-1}\right)$ & 0.22 \\
\hline Color & Colorless \\
\hline
\end{tabular}

a molecule to exchange electron density with the environment.

(3) Electrophilicity: in 1999, Parr defined the electrophilicity index [40] $\boldsymbol{\omega}=\boldsymbol{\mu}^{2} / 2 \eta$, which measures the total ability to attract electrons. The electrophilicity index gives a measure of the energy stabilization of a molecule when it acquires an additional amount of electron density from the environment. The electrophilicity index comprises the tendency of an electrophile to acquire an extra amount of electron density, given by $\boldsymbol{\mu}$ and the resistance of a molecule to exchange electron density with the environment, given by $\boldsymbol{\eta}$. Therefore, a good electrophile is a species characterized by a high absolute $\mu$ value and a low $\boldsymbol{\eta}$ value. The electrophilicity index has become a powerful tool for the study of the reactivity of organic molecules [36].

(4) Nucleophilicity $(N)$ : while the electrophilicity of the molecules accounts for the reactivity towards nucleophiles, it has been shown by Domingo and his coworkers [36-39] that a simple index chosen for the nucleophilicity, $N$, based on the HOMO energy, within DFT, is useful to explain the reactivity of these new compounds towards electrophiles.

Nucleophilicity index is defined as $N=$ $E_{\text {Hомо }}(\mathrm{eV})+9.12(\mathrm{eV})$, where -9.12 is the energy of the HOMO of tetracyanoethylene (TCE).

It is noteworthy to mention that this nucleophilicity scale is referred to tetracyanoethylene (TCE) taken as 
TABle 2: Geometric parameters $\left(\AA,^{\circ}\right)$.

\begin{tabular}{|c|c|c|}
\hline Bonds and angles & X-ray & Modeled \\
\hline S1-C13 & $1.721(4)$ & 1.7997 \\
\hline S1-C17 & $1.707(4)$ & 1.8053 \\
\hline $\mathrm{O} 2-\mathrm{C} 7$ & $1.214(4)$ & 1.2438 \\
\hline N3-C7 & $1.369(5)$ & 1.3731 \\
\hline N3-C17 & $1.382(4)$ & 1.3864 \\
\hline N4-C17 & $1.309(4)$ & 1.3014 \\
\hline $\mathrm{N} 4-\mathrm{C} 10$ & $1.379(5)$ & 1.4034 \\
\hline N5-C16 & $1.391(4)$ & 1.3853 \\
\hline N5-C9 & $1.437(4)$ & 1.4389 \\
\hline C6-C15 & $1.355(5)$ & 1.386 \\
\hline C6-C16 & $1.397(5)$ & 1.4087 \\
\hline C7-C9 & $1.519(5)$ & 1.5211 \\
\hline C8-C14 & $1.381(5)$ & 1.3928 \\
\hline C8-C15 & $1.384(5)$ & 1.403 \\
\hline C8-C12 & $1.508(5)$ & 1.5147 \\
\hline $\mathrm{C} 10-\mathrm{C} 13$ & $1.321(5)$ & 1.3513 \\
\hline C11-C14 & $1.378(5)$ & 1.3967 \\
\hline C11-C16 & $1.385(5)$ & 1.4023 \\
\hline N3-H3 & 0.9598 & 1.0171 \\
\hline N5-H5 & 0.9600 & 1.0139 \\
\hline C6-H6 & 0.9600 & 1.0861 \\
\hline C9-H9A & 0.9599 & 1.103 \\
\hline C9-H9B & 0.9600 & 1.103 \\
\hline $\mathrm{C} 10-\mathrm{H} 10$ & 0.9601 & 1.0787 \\
\hline C11-H11 & 0.9602 & 1.0845 \\
\hline C12-H12A & 0.9600 & 1.0946 \\
\hline C12-H12B & 0.9600 & 1.0963 \\
\hline $\mathrm{C} 12-\mathrm{H} 12 \mathrm{C}$ & 0.9600 & 1.0963 \\
\hline $\mathrm{C} 13-\mathrm{H} 13$ & 0.9600 & 1.0777 \\
\hline C14-H14 & 0.9602 & 1.0865 \\
\hline $\mathrm{C} 15-\mathrm{H} 15$ & 0.9601 & 1.0867 \\
\hline C13-S1-C17 & $87.9(2)$ & 86.3009 \\
\hline C7-N3-C17 & $123.7(3)$ & 125.9603 \\
\hline C17-N4-C10 & $108.1(3)$ & 111.3904 \\
\hline C16-N5-C9 & $121.1(3)$ & 122.897 \\
\hline C15-C6-C16 & $120.3(4)$ & 120.6207 \\
\hline $\mathrm{O} 2-\mathrm{C} 7-\mathrm{N} 3$ & $122.8(4)$ & 122.4876 \\
\hline $\mathrm{O} 2-\mathrm{C} 7-\mathrm{C} 9$ & $124.6(4)$ & 123.1669 \\
\hline N3-C7-C9 & $112.6(4)$ & 114.3456 \\
\hline C14-C8-C15 & $116.2(4)$ & 117.6113 \\
\hline C14-C8-C12 & $121.8(4)$ & 121.8524 \\
\hline C15-C8-C12 & $121.9(4)$ & 120.5363 \\
\hline N5-C9-C7 & $109.7(3)$ & 108.4 \\
\hline C13-C10-N4 & $116.7(4)$ & 115.7669 \\
\hline C14-C11-C16 & $121.4(4)$ & 119.8642 \\
\hline $\mathrm{C} 10-\mathrm{C} 13-\mathrm{S} 1$ & $110.6(3)$ & 111.058 \\
\hline C8-C14-C11 & $121.5(4)$ & 121.6167 \\
\hline C6-C15-C8 & $123.3(4)$ & 121.5706 \\
\hline C11-C16-N5 & $123.5(4)$ & 122.0228 \\
\hline C11-C16-C6 & $117.1(4)$ & 118.1129 \\
\hline N5-C16-C6 & $119.4(4)$ & 119.8642 \\
\hline N4-C17-N3 & $119.5(3)$ & 121.0122 \\
\hline N4-C17-S1 & $116.6(3)$ & 115.4839 \\
\hline
\end{tabular}

TABLE 2: Continued.

\begin{tabular}{lcc}
\hline Bonds and angles & X-ray & Modeled \\
\hline N3-C17-S1 & $123.9(3)$ & 123.504 \\
C7-N3-H3 & 119.5 & 120.0392 \\
C17-N3-H3 & 116.8 & 114.0005 \\
C16-N5-H5 & 120.7 & 120.8726 \\
C9-N5-H5 & 118.2 & 116.2304 \\
C15-C6-H6 & 122.1 & 119.9912 \\
C16-C6-H6 & 117.5 & 119.3881 \\
N5-C9-H9A & 108.9 & 119.3881 \\
C7-C9-H9A & 110.6 & 108.6962 \\
N5-C9-H9B & 108.2 & 111.6719 \\
C7-C9-H9B & 109.9 & 108.6961 \\
H9A-C9-H9B & 109.5 & 107.5286 \\
C13-C10-H10 & 124.8 & 126.0377 \\
N4-C10-H10 & 118.4 & 118.1954 \\
C14-C11-H11 & 119.2 & 118.9467 \\
C16-C11-H11 & 119.4 & 120.5856 \\
C8-C12-H12A & 109.8 & 110.988 \\
C8-C12-H12B & 109.1 & 110.9831 \\
H12A-C12-H12B & 109.5 & 107.9859 \\
C8-C12-H12C & 109.5 & 110.9833 \\
H12A-C12-H12C & 109.5 & 107.7767 \\
H12B-C12-H12C & 109.5 & 107.9859 \\
C10-C13-H13 & 129.4 & 128.4417 \\
S1-C13-H13 & 120.0 & 120.5003 \\
C8-C14-H14 & 119.0 & 119.5425 \\
C11-C14-H14 & 119.5 & 118.8408 \\
C6-C15-H15 & 117.9 & 119.1455 \\
C8-C15-H15 & 118.8 & 119.2839 \\
\hline & & \\
& &
\end{tabular}

a reference, because it presents the lowest HOMO energy in a large series of molecules investigated [36].

The numerical parameters reflect the tendency of transferring electronic charges during chemical interactions between molecules (Table 3). Electrophilicity is an important reactivity descriptor that is considered as a measure of a compound's willingness to participate as an electron acceptor during a chemical reaction, or, in other words, the electron deficiency of a compound. $3 \mathrm{E}$ is the molecule with the largest electrophilicity $\boldsymbol{\omega}$, whereas $3 \mathrm{D}$ is the one showing smallest electrophilicity indicating lower susceptibility towards nucleophilic reaction. Table 3 shows that chemical potential value, which is the negative of molecular electronegativity reflecting the escaping tendency of electrons, decreases in the following order: $3 \mathrm{D}>2 \mathrm{~B}>3 \mathrm{~B}>2 \mathrm{C}>3 \mathrm{~A}>2 \mathrm{~F}>2 \mathrm{D}>2 \mathrm{E}>2 \mathrm{~A}>3 \mathrm{C}>$ $3 \mathrm{E}$.

By examining the nucleophilicity descriptor $N$ (Table 3) for these molecules, we found that $2 \mathrm{E}(\mathrm{N}=0.78 \mathrm{eV})$ is one of the poorest nucleophiles of this series, while $3 \mathrm{D}(\mathrm{N}=2.97 \mathrm{eV})$ represents the best nucleophile. Generally, nucleophilicity increases in the following order: $2 \mathrm{E}<2 \mathrm{~A}<3 \mathrm{C}<3 \mathrm{E}<2 \mathrm{C}<$ $2 \mathrm{~B}<2 \mathrm{~F}<2 \mathrm{D}<3 \mathrm{~B}<3 \mathrm{~A}<3 \mathrm{D}$

These results are consistent with the expected reactivity pattern. 
TABLE 3: Reactivity indices* sorted according to ascending electrophilicity $\omega$.

\begin{tabular}{|c|c|c|c|c|c|c|}
\hline Molecule & HOMO & LUMO & $\mu$ & $\eta$ & $\omega$ & $N$ \\
\hline 1 & -7.78 & 1.90 & -2.94 & 4.84 & 0.64 & 1.34 \\
\hline $3 \mathrm{D}$ & -6.15 & 1.31 & -2.42 & 3.73 & 0.79 & 2.97 \\
\hline $2 \mathrm{~B}$ & -7.61 & 1.99 & -2.81 & 4.55 & 0.87 & 1.51 \\
\hline $2 \mathrm{C}$ & -7.80 & 1.28 & -3.26 & 4.54 & 1.17 & 1.32 \\
\hline $3 B$ & -7.20 & 0.97 & -3.12 & 4.09 & 1.19 & 1.92 \\
\hline $2 \mathrm{~F}$ & -7.61 & 1.04 & -3.29 & 4.33 & 1.25 & 1.51 \\
\hline $3 \mathrm{~A}$ & -6.96 & 0.59 & -3.19 & 3.78 & 1.34 & 2.16 \\
\hline $2 \mathrm{D}$ & -7.42 & 0.53 & -3.45 & 3.98 & 1.49 & 1.70 \\
\hline $2 \mathrm{E}$ & -8.34 & 0.91 & -3.72 & 4.63 & 1.50 & 0.78 \\
\hline $2 \mathrm{~A}$ & -8.31 & 0.73 & -3.79 & 4.52 & 1.59 & 0.81 \\
\hline $3 \mathrm{C}$ & -8.19 & 0.29 & -3.95 & 4.24 & 1.84 & 0.93 \\
\hline $3 \mathrm{E}$ & -8.11 & 0.08 & -4.02 & 4.10 & 1.97 & 1.01 \\
\hline
\end{tabular}

${ }^{*} \mathrm{HOMO}$, LUMO, $\mu, \eta$, and $N$ are in $\mathrm{eV}$.

Investigation of a molecule's surface is probably a good start for considerations of the molecule's reactivity since this is where two approaching molecules would first interact. ESP maps are depicted in Figure 2. The results should improve our knowledge about the binding sites, which are of importance in chemical reactivities and medical applications. Color codes point to the binding sites when interacting with other reagents [41-43] (see caption of Figure 2).

\section{Conclusions}

One-step syntheses of 12 thiazole derivatives of medicinal importance are performed. Optimized structures, reactivity indices, electrostatic potential energy maps, and spectroscopic properties such as IR and NMR of the newly reported molecules are computed within DFT using WB97XD/6$31 \mathrm{G}(\mathrm{d})$ model. Satisfactory agreement between experiment and theory is observed. Trends in chemical reactivities are investigated. Molecules $3 \mathrm{E}$ and $3 \mathrm{D}$ have the largest and smallest electrophilicity, respectively. Generally, based on relative nucleophilicity index $N$, nucleophilicity increases in the following order: $2 \mathrm{E}<2 \mathrm{~A}<3 \mathrm{C}<3 \mathrm{E}<2 \mathrm{C}<2 \mathrm{~B}<2 \mathrm{~F}<2 \mathrm{D}<$ $3 \mathrm{~B}<3 \mathrm{~A}<3 \mathrm{D}$. These results are consistent with the expected reactivity pattern.

The graphically visualized ESP maps enable locating the binding sites of these molecules.

\section{Conflicts of Interest}

The authors declare that they have no conflicts of interest.

\section{References}

[1] C. H. Oh, H. W. Cho, D. Baek, and J. H. Cho, "Synthesis and antibacterial activity of $1 \beta$-methyl-2-(5-substituted thiazole pyrrolidin-3-ylthio) carbapenem derivatives," European Journal of Medicinal Chemistry, vol. 37, pp. 743-754, 2002.
[2] R. A. Tapia, Y. Prieto, F. Pautet et al., "Synthesis and antiprotozoal evaluation of benzothiazolopyrroloquinoxalinones, analogues of kuanoniamine A," Bioorganic and Medicinal Chemistry, vol. 11, no. 16, pp. 3407-3412, 2003.

[3] G. V. Suresh Kumar, Y. Rajendraprasad, B. P. Mallikarjuna, S. M. Chandrashekar, and C. Kistayya, "Synthesis of some novel 2-substituted-5-[isopropylthiazole] clubbed 1,2,4-triazole and 1,3,4-oxadiazoles as potential antimicrobial and antitubercular agents," European Journal of Medicinal Chemistry, vol. 45, no. 5, pp. 2063-2074, 2010.

[4] P. Samadhiya, R. Sharma, S. K. Srivastava, and S. D. Srivastava, "Synthesis of 2-oxoazetidine derivatives of 2-aminothiazole and their biological activity," Journal of the Serbian Chemical Society, vol. 77, no. 5, pp. 599-605, 2012.

[5] S. K. Sonwane and S. D. Srivastava, "Synthesis and biological significance of 2-amino-4-phenyl-1,3-thiazole derivatives," Proceedings of the National Academy of Sciences, India, vol. 78, no. 2, pp. 129-136, 2008.

[6] S. K. Srivastava, R. Yadav, and S. D. Srivastava, "Synthesis and biological activity of 4-oxothiazolidines and their 5-arylidenes," Indian Journal of Chemistry, vol. 43B, no. 2, pp. 399-405, 2004.

[7] S. Ghaemmaghami, B. C. H. May, A. R. Renslo, and S. B. Prusiner, "Discovery of 2-aminothiazoles as potent antiprion compounds," Journal of Virology, vol. 84, no. 7, pp. 3408-3412, 2010.

[8] H. L. Siddiqui, M. Zia-Ur-Rehman, N. Ahmad, G. W. Weaver, and P. D. Lucas, "Synthesis and antibacterial activity of bis[2amino-4-phenyl-5-thiazolyl] disulfides," Chemical and Pharmaceutical Bulletin, vol. 55, no. 7, pp. 1014-1017, 2007.

[9] E. A. Kesicki, M. A. Bailey, Y. Ovechkina et al., "Synthesis and evaluation of the 2-aminothiazoles as anti-tubercular agents," PLOS ONE, vol. 11, no. 5, 2016.

[10] P. Lin, R. Hou, H. Wang, I. Kang, and L. Chen, "Efficient Synthesis of 2-Aminothiazoles and Fanetizole in Liquid PEG400 at Ambient Conditions," Journal of the Chinese Chemical Society, vol. 56, no. 3, pp. 455-458, 2009.

[11] M. J. Gorczynski, R. M. Leal, S. L. Mooberry, J. H. Bushweller, and M. L. Brown, "Synthesis and evaluation of substituted 4-aryloxy- and 4-arylsulfanyl- phenyl-2-aminothiazoles 
as inhibitors of human breast cancer cell proliferation," Bioorganic and Medicinal Chemistry, vol. 12, no. 5, pp. 1029-1036, 2004.

[12] R. N. Misra, H.-Y. Xiao, D. K. Williams et al., "Synthesis and biological activity of $\mathrm{N}$-aryl-2-aminothiazoles: potent pan inhibitors of cyclin-dependent kinases," Bioorganic and Medicinal Chemistry Letters, vol. 14, no. 11, pp. 2973-2977, 2004.

[13] H. I. El-Subbagh, A. H. Abadi, and J. Lehmann, "Synthesis and Antitumor Activity of Ethyl 2-Substituted-aminothiazole4-carboxylate Analogs," Archiv der Pharmazie, vol. 332, no. 4, pp. 137-142, 1999.

[14] I. Kayagil and S. Demirayak, "Synthesis and anticancer activities of some thiazole derivatives," Phosphorus, Sulfur and Silicon and the Related Elements, vol. 184, no. 9, pp. 2197-2207, 2009.

[15] Priyanka, K. S. Neeraj, and K. J. Keshari, "Benzothiazole: the molecule of diverse biological activities," International Journal of Current Pharmaceutical Research, vol. 2, p. 1, 2010.

[16] H. P. Singh, C. S. Sharma, and C. P. Gautam, "Synthesis and pharmacological screening of some novel 2-arylhydrazino and 2-aryloxy-pyrimido [2,1-b] benzothiazole derivatives," American-Eurasian Journal of Scientific Research, vol. 4, no. 4, pp. 222-228, 2009.

[17] H. Kaur, S. Kumar, I. Singh, K. K. Saxena, and A. Kumar, "Synthesis, characterization and biological activity of various substituted benzothiazole derivatives," Digest Journal of Nanomaterials \& Biostructures, vol. 5, no. 1, pp. 67-76, 2010.

[18] A. A. Chavan and N. R. Pai, "Synthesis and biological activity of N-substituted-3-chloro-2-azetidinones," Molecules, vol. 12, no. 11, pp. 2467-2477, 2007.

[19] S. Nadeem, R. Arpana, A. K. Suroor et al., "Synthesis and preliminary screening of benzothiazol-2-yl thiadiazole derivatives for anticonvulsant activity," Acta Pharmaceutica, vol. 59, no. 4, pp. 441-451, 2009.

[20] N. A. Masoudi, W. Pfleiderer, and C. Pannecouque, "Nitroimidazoles part 7. synthesis and anti-HIV activity of new 4nitroimidazole derivatives," Zeitschrift für Naturforschung $B$, vol. 67, no. 8, pp. 835-842, 2014.

[21] P. Gajdoš, P. Magdolen, P. Zahradník, and P. Foltínová, “New conjugated benzothiazole-N-oxides: synthesis and biological activity," Molecules, vol. 14, no. 12, pp. 5382-5388, 2009.

[22] R. K. Gill, R. K. Rawal, and J. Bariwal, "Recent advances in the chemistry and biology of benzothiazoles," Archiv der Pharmazie, vol. 348, no. 3, pp. 155-178, 2015.

[23] R. Paramashivappa, P. Phani Kumar, P. V. Subba Rao, and A. Srinivasa Rao, Bioorg.Med. Chem. Lett, vol. 13, p. 657, 2003.

[24] D. Shashank, T. Vishawanth, M. Arif Pasha et al., "Synthesis of some substituted benzothiazole derivaties and its biological activities," International Journal of ChemTech Research, vol. 1, no. 4, pp. 1224-1231, 2009.

[25] C. Papadopoulou, A. Geronikaki, and D. HadjipavlouLitina, "Synthesis and biological evaluation of new thiazolyl/benzothiazolyl-amides, derivatives of 4-phenylpiperazine," II Farmaco, vol. 60, no. 11-12, pp. 969-973, 2005.

[26] E. Theophil and H. Siegfried, The Chemistry of Heterocycles Structure: Reactions, Syntheses, and Applications, Wiley-VCH, Verlag GmbH, and Co., Weinheim, Germany, 2nd edition, 2003.

[27] B. S. Dawane, S. G. Konda, V. T. Kamble, S. A. Chavan, R. B. Bhosale, and B. M. Shaikh, "Multicomponent one-pot synthesis of substituted hantzsch thiazole derivatives under solvent free conditions," E-Journal of Chemistry, vol. 6, no. 1, pp. S358-S362, 2009.
[28] D. Lednicer, L. A. Mitscher, and G. I. Georg, Organic Chemistry of Drug Synthesis, vol. 4, John Wiley \&amp; Sons, Inc., New York, NY, USA, 1990.

[29] K. S. Kim, S. D. Kimball, R. N. Misra, D. B. Rawlins et al., "Discovery of aminothiazole inhibitors of cyclin-dependent kinase 2: synthesis, X-ray crystallographic analysis, and biological activities," J. Med. Chem, vol. 45, no. 18, pp. 3905-3927, 2002.

[30] O. Annen, R. Egli, R. Hasler, B. Henzi, H. Jakob, and P. Matzinger, "Replacement of disperse anthraquinonedyeS," Review of Progress in Coloration and Related Topics, vol. 17, no. 1, pp. 72-85, 1987.

[31] L. Shuttleworth and M. A. Weaver, The Chemistry and Application of Dyes, Plenum Press, New York, NY, USA, 1990.

[32] M. J. Frisch, G. W. Trucks, H. B. Schlegel et al., Gaussian, Inc., Wallingford CT, 2016.

[33] P. Geerlings, F. de Proft, and W. Langenaeker, "Conceptual density functional theory," Chemical Reviews, vol. 103, no. 5, pp. 1793-1874, 2003.

[34] Foresman J. B. and A. Frisch, Exploring chemistry with electronic structure methods, Gaussian, Inc., Wallingford, CT, USA, 3rd edition, 2015.

[35] I. Fleming, Frontier Orbitals and Organic Chemical Reactions, John Wiley and Sons, New York, NY, USA, 1976.

[36] L. R. Domingo, E. Chamorro, and P. Pérez, "Understanding the reactivity of captodative ethylenes in polar cycloaddition reactions. A theoretical study," Journal of Organic Chemistry, vol. 73, no. 12, pp. 4615-4624, 2008.

[37] L. R. Domingo, M. Ríos-Gutiérrez, and P. Pérez, "Applications of the conceptual density functional theory indices to organic chemistry reactivity," Molecules, vol. 21, no. 6, article no. 748, 2016.

[38] L. R. Domingo, "A new C-C bond formation model based on the quantum chemical topology of electron density," RSC Advances, vol. 4, no. 61, pp. 32415-32428, 2014.

[39] L. R. Domingo, "Molecular electron density theory: a modern view of reactivity in organic chemistry," Molecules, vol. 21, no. 10, article no. 1319, 2016.

[40] F. Zielinski, V. Tognetti, and L. Joubert, "Condensed descriptors for reactivity: a methodological study," Chemical Physics Letters, vol. 527, pp. 67-72, 2012.

[41] JS. Murray and K. Sen, Molecular Electrostatic Potentials, Concepts and Applications, Elsevier, Amsterdam, Netherlands, 1996.

[42] P. Politzer and J. S. Murray, "The fundamental nature and role of the electrostatic potential in atoms and molecules," Theoretical Chemistry Accounts, vol. 108, no. 3, pp. 134-142, 2002.

[43] J. S. Murray and P. Politzer, "The electrostatic potential: an overview," Wiley Interdisciplinary Reviews: Computational Molecular Science, vol. 1, no. 2, pp. 153-163, 2011. 

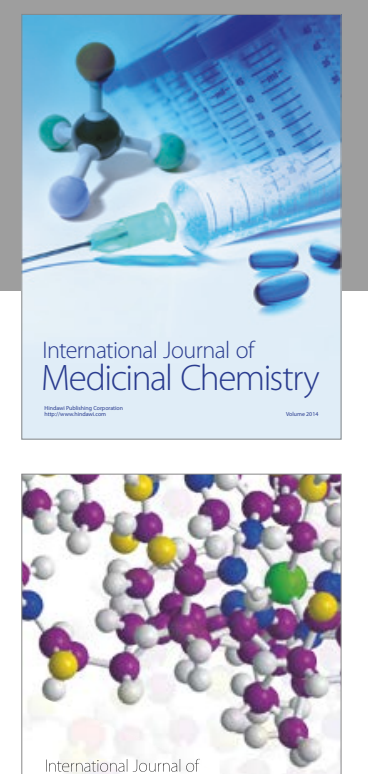

Carbohydrate Chemistry

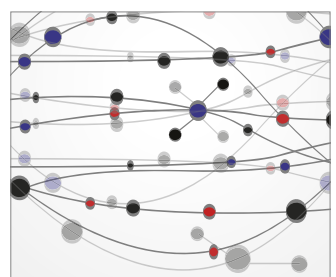

The Scientific World Journal
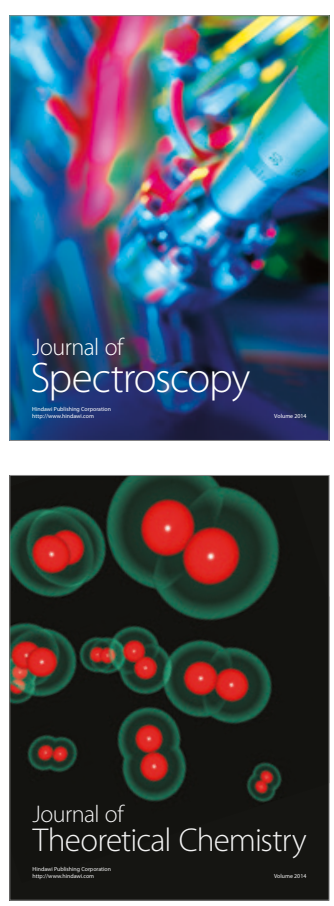
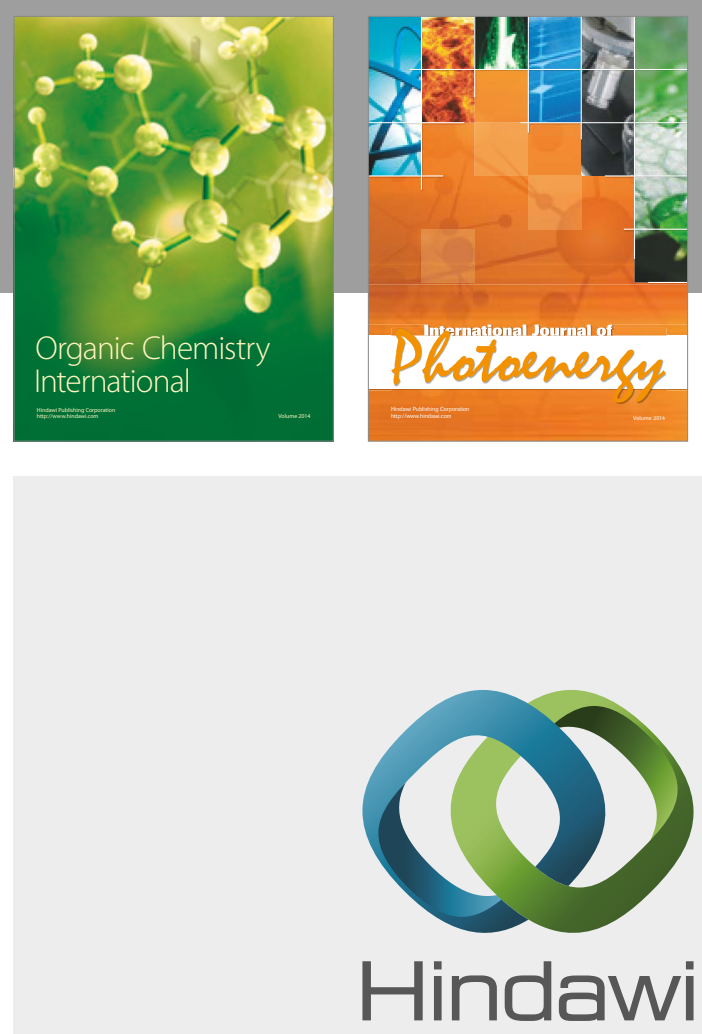

Submit your manuscripts at

https://www.hindawi.com

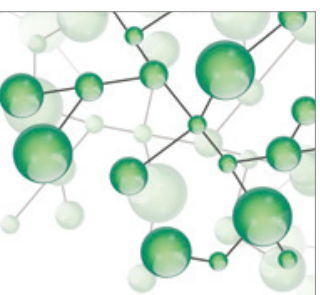

International Journal of

Inorganic Chemistry

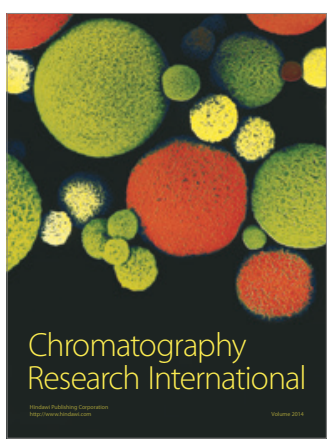

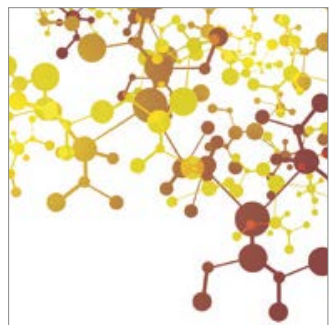

Applied Chemistry
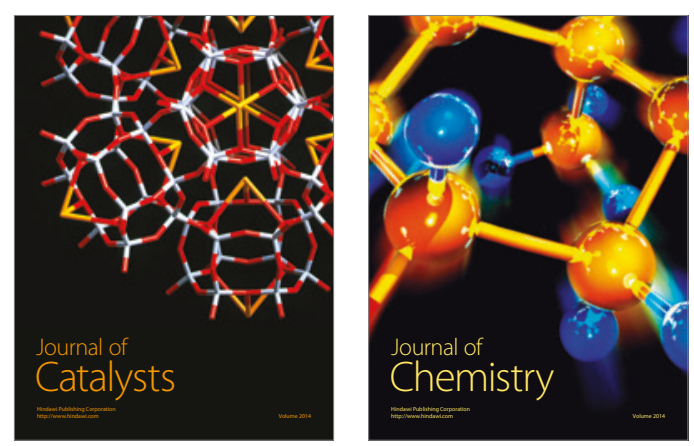
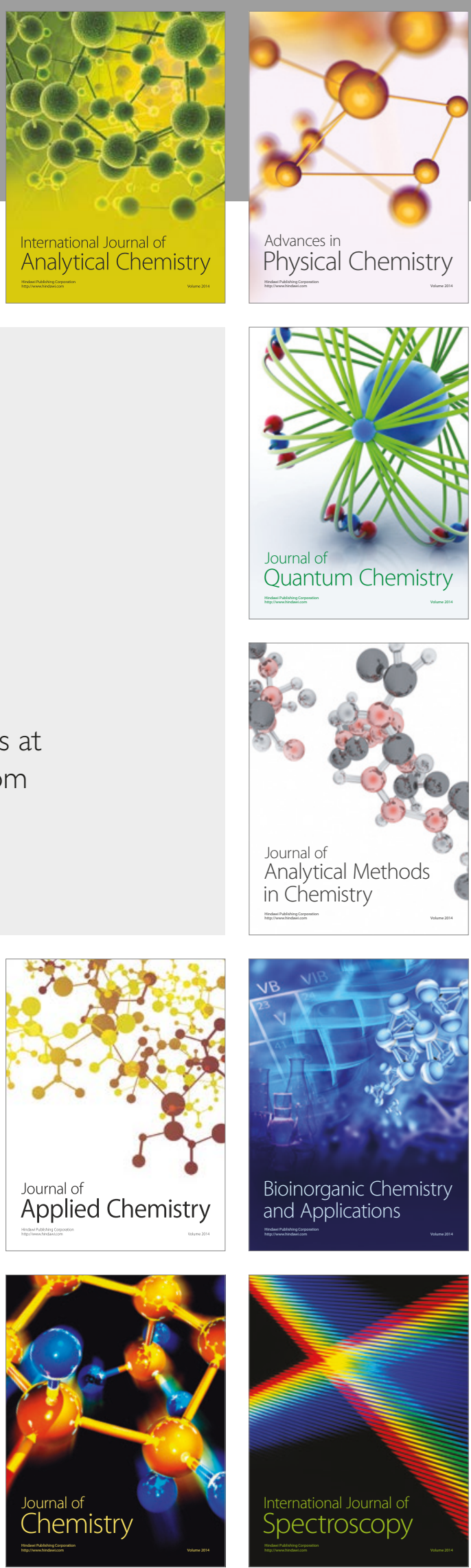